\title{
Pengembangan Kelembagaan Pembibitan Ternak Sapi Melalui Pola Integrasi Tanaman-Ternak
}

\author{
Cahyati Setiani dan Teguh Prasetyo \\ Balai Pengkajian Teknologi Pertanian Jawa Tengah, Ungaran
}

\section{INTISARI}

Pengkajian mengenai Pengembangan Pembibitan Ternak Sapi dilakukan di Desa Karangjambe, Kecamatan Wanadadi, Kabupaten Banjarnegara dan Desa Kalipoh, Kecamatan Ayah, Kabupaten Kebumen tahun 2004. Tujuan pengkajian adalah untuk mendapatkan model pembibitan ternak sapi yang sesuai dengan kondisi sumberdaya alam, sumberdaya manusia dan budaya yang berkembang di masyarakat perdesaan. Metode pengkajian yang digunakan adalah survey baik melalui wawancara dengan responden dan key informan maupun observasi lapang. Responden adalah anggota kelompok tani Bumi Mulyo (Kabupaten Banjarnegara) dan Becik Asih (Kabupaten Kebumen). Key informan adalah pengurus kelompok tani, aparat desa, serta petugas yang terkait dengan pengembangan pembibitan ternak sapi. Pola pengembangan usaha pembibitan dilakukan melalui bantuan pinjaman langsung masyarakat (BPLM) dan integrasi tanaman-ternak. Sumberdaya alam di Desa Karangjambe didominasi tanah alluvial dan grumosol yang lahan pertanian utamanya berupa lahan sawah dengan pola tanam padi-padi-palawija, sedangkan di Desa Kalipoh didominasi tanah alluvial, lahan kering dengan pola tanam jagung-jagung+ketela pohon. Kelembagaan pembibitan sapi yang berkembang di kelompok tani Bumi Mulyo adalah: jangka waktu pelunasan 4 tahun, mengembalikan pinjaman pokok (ternak bibit+konsentrat) tanpa bunga. Apabila pedet yang dihasilkan betina, pada umur 15 sampai 18 bulan digulirkan kepada anggota lain, namun jika yang dihasilkan pedet jantan, hasil penjualan dibagi 50\%: 50\%, masing-masing untuk penggaduh dan kelompok, sedangkan di kelompok tani Becik Asih jangka waktu pelunasan 3 tahun, peternak berhak atas ternak pokok dan $70 \%$ hasil penjualan pedet yang dihasilkan, berkewajiban mengembalikan pinjaman pokok untuk pembelian ternak bibit dengan jumlah sesuai dengan akad kredit.

Kata kunci: kelembagaan, pembibitan ternak sapi, integrasi tanaman-ternak

\section{PENDAHULUAN}

Tujuan usaha peternakan sapi potong rakyat, meliputi: pembibitan (reproduksi) dan penggemukan. Pembibitan sapi potong merupakan upaya peningkatan produksi ternak yang pada umumnya dilakukan di dataran rendah dengan ketersediaan pakan relatif kurang (Hardjosubroto, 2003). Fenomena ini mengindikasikan bahwa kurang berkembangnya usaha pembibitan sapi potong, apabila upaya dan terobosan melalui penerapan inovasi dan teknologi tidak dilakukan, diprediksi ketergantungan Indonesia terhadap impor akan mencapai $70 \%$ (Quirke dalam Dwiyanto dan
Handirawan, 2004). Pada tahun 2002 impor sapi bakalan mencapai 400.000 ekor dan daging setara dengan 120.000 sapi potong yang berarti $30 \%$ dari konsumsi daging sapi adalah impor (Kariyasa dan Kasryno, (2004). Guna mencapai keseimbangan penawaran dan permintaan, mengurangi ketergantungan impor, dan memenuhi kecukupan daging 2010 dilakukan pengembangan kelembagaan perbibitan ternak sapi oleh Dinas Peternakan Provinsi Jawa Tengah melalui pendekatan Bantuan Pinjaman Langsung Masyarakat (BPLM). Pendekatan BPLM ditujukan pada kelompok tani-ternak yang dianggap potensial bagi pengembangan pembibitan 
sapi, dua diantaranya adalah di wilayah Kabupaten Banjarnegara dan Kebumen. Dalam implementasi di lapang usaha pembibitan ternak sapi dikaitkan dengan usaha tanaman yang diusahakan oleh petani - ternak, utamanya sebagai sumber pakan (Dinas Peternakan Provinsi Jawa Tengah, 2004).

Berkaitan dengan hal tersebut di atas, diperlukan pengkajian tentang kelembagaan pembibitan ternak sapi. Tujuan pengkajian adalah untuk mendapatkan model pengembangan kelembagaan pembibitan sapi yang sesuai dengan kondisi sumberdaya alam, sumberdaya manusia dan budaya masyarakat setempat. Hasil pengkajian diharapkan dapat menjadi bahan masukan bagi penentu kebijakan dalam mengembangkan usaha pembibitan ternak sapi.

\section{MATERI DAN METODE}

Pengkajian penelitian ini mengenai pengembangan kelembagaan perbibitan ternak sapi melalui pola integrasi tanamanternak dilakukan di Desa Karangjambe, Kecamatan Wanadadi, Kabupaten Banjarnegara dan Desa Kalipoh, Kecamatan Ayah, Kabupaten Kebumen tahun 2004.

Metode pengkajian yang digunakan adalah survey baik melalui wawancara dengan responden dan key informan maupun observasi lapang. Responden adalah anggota kelompok tani Bumi Mulyo (Kabupaten Banjarnegara) dan Becik Asih (Kabupaten Kebumen). Key informan adalah pengurus kelompok tani, aparat desa, serta petugas yang terkait dengan pengembangan pembibitan ternak sapi. Pola pengembangan usaha pembibitan dilakukan melalui bantuan pinjaman langsung masyarakat (BPLM) dan integrasi tanaman-ternak.

\section{HASIL DAN PEMBAHASAN}

\section{Karakteristik Sumberdaya Alam}

Lokasi pengembangan BPLM perbibitan sapi potong dari aspek topografi digolongkan sebagai dataran rendah, dengan ketinggian di masing-masing lokasi adalah : Kabupaten Banjarnegara $40 \mathrm{~m}$ di atas permukaan laut (dpl), Kebumen 150 sampai $200 \mathrm{~m}$ dpl. Berdasarkan kemiringan lahan, kondisi topografi Banjarnegara datar-agak miring, dan Kebumen bertopografi bergelombang. Secara umum jenis tanah di Banjarnegara berjenis aluvial dan grumosol, sedangkan Kebumen aluvial.

Ledakan penduduk menyebabkan jumlah rumah tangga (petani) meningkat, di sisi lain tidak diimbangi dengan luas lahan yang dikuasai petani, sehingga mengakibatkan jumlah petani gurem semakin meningkat. Dalam Sensus Pertanian 1993 disebutkan, bahwa yang disebut petani gurem adalah yang menguasai lahan kurang dari 0,5 ha. Kondisi tersebut juga terjadi di lokasi pengembangan BPLM perbibitan sapi potong. Kabupaten Banjarnegara didominasi oleh lahan sawah irigasi, dengan pola tanam padi-padipalawija. Tanaman palawija yang diusahakan didominasi oleh jagung. Kabupaten Kebumen didominasi oleh lahan kering dengan tanaman yang diusahakan mayoritas jagung dan ketela pohon.

\section{Karakteristik Sumberdaya Manusia}

Apabila mengacu pada batasan yang ditentukan International Labor Organization (ILO), bahwa usia kerja berkisar 15 sampai 64 tahun, maka dapat dikatakan bahwa seluruh penggaduh berada dalam umur produktif, karena sebagian besar penggaduh berumur 25-45 tahun. Pada kelompok umur tersebut dikategorikan sebagai pengetrap dini dan pengetrap awal suatu inovasi teknologi. Mengingat adopsi suatu inovasi berkaitan dengan produktivitas, maka umur petani merupakan salah satu faktor yang akan mempengaruhi produktivitas usaha sapi potong.

Teknologi yang berkembang saat ini dalam rangka perbibitan sapi potong menuntut kemampuan petani untuk mengadopsi suatu inovasi. Pendidikan memegang peran penting bagi petani untuk 
memutuskan untuk mengadopsi suatu inovasi. Kualitas SDM antara lain dicerminkan dari tingkat pendidikan formalnya. Sebagian besar (60 sampai 83\%) penggaduh di Kabupaten Banjarnegara dan Kebumen berpendidikan SD. Di negara berkembang, beberapa anggota masyarakat masih memandang anak dari sisi manfaatnya, yakni di masa depan akan memberikan balas jasa ekonomi maupun dalam proses produksi, sehingga jumlah tanggungan keluarga petani dapat juga mencerminkan besarnya jumlah tenaga kerja yang dapat memberikan kontribusi dalam berusahatani. Dengan demikian, anggota keluarga merupakan sumber tenaga kerja untuk melaksanakan usahatani. Slamet (1994)) menyatakan bahwa aktivitas ekonomi petani dipengaruhi oleh besarnya tanggungan keluarga petani. Petani akan meningkatkan aktivitas ekonominya, baik pada sektor pertanian maupun non pertanian, jika jumlah tanggungan keluarga semakin besar. Jumlah tanggungan keluarga penggaduh berkisar 3 sampai 5 orang. Apabila dilihat dari mata pencaharian pokok penggaduh, $60-80 \%$ menggantungkan hidupnya dari pertanian, baik sebagai petani penggarap maupun buruh tani, dan tidak satupun petani yang menjadikan usaha sapi potong sebagai mata pencaharian pokok. Usaha sapi masih sebatas usaha sampingan hingga cabang usaha, untuk memanfaatkan tenaga kerja luang diantara kegiatan usahataninya. Soekartawi (1993) menyatakan bahwa beternak merupakan salah satu cara untuk memanfaatkan kelebihan tenaga kerja petani.

\section{Kelembagaan Perbibitan Ternak Sapi}

\section{Model Perguliran}

Dana BPLM untuk bantuan usaha ekonomi produktif (perbibitan sapi potong) penyalurannya dilakukan melalui Kantor Perbendaharaan dan Kas Negara (KPKN) setempat, dengan tata cara pembayaran langsung (LS), yakni pemindahbukuan (transfer) dana dari rekening Kas Negara ke rekening kelompok tani pada Kantor Cabang atau unit bank penyalur. Pengembangan dana tersebut dilakukan dengan cara perguliran kepada anggota kelompok tani. Model perguliran yang dikembangkan sesuai surat perjanjian di masing-masing kabupaten disajikan pada Tabel 1.

Tabel 1. Model perguliran yang diterapkan pada BPLM di Kabupaten Banjarnegara dan Kebumen

\begin{tabular}{|c|c|c|}
\hline \multirow[t]{2}{*}{ Uraian } & \multicolumn{2}{|c|}{ Lokasi } \\
\hline & Banjarnegara & Kebumen \\
\hline \multicolumn{3}{|l|}{ 1. Jangka waktu: } \\
\hline-3 tahun & & $\mathbf{V}$ \\
\hline - 4 tahun & $\mathbf{V}$ & \\
\hline \multicolumn{3}{|l|}{ 2. Hak peternak atas pedet } \\
\hline$-70 \%$ & & $\mathbf{V}$ \\
\hline$-100 \%$ & $\mathbf{V}$ & \\
\hline \multicolumn{3}{|c|}{ 3. Pengembalian pinjaman pokok } \\
\hline - Sesuai akad kredit & $\mathbf{V}$ & V \\
\hline - Penjualan ternak pokok & & \\
\hline - Tidak diatur & & \\
\hline 4. Bunga pinjaman & & \\
\hline - Ada & & \\
\hline - Tidak ada & $\mathbf{V}$ & $\mathbf{V}$ \\
\hline
\end{tabular}


Tabel 2. Jumlah peternak penerima BPLM dan dana yang diterima di Kabupaen Banjarnegara dan Kebumen

\begin{tabular}{llccl}
\hline \hline No. & $\begin{array}{l}\text { KTT/Kabupaten } \\
\text { penerima BPLM }\end{array}$ & $\begin{array}{c}\text { Jumlah petani } \\
\text { (orang) }\end{array}$ & $\begin{array}{c}\text { Jumlah dana } \\
\text { BPLM } \\
\text { (Rp.) }\end{array}$ & \multicolumn{1}{l}{ Keterangan } \\
\hline 1. & $\begin{array}{l}\text { Bumi Mulyo/ } \\
\text { Banjarnegara }\end{array}$ & 17 & 127.000 .000 & $\begin{array}{l}\text { Pengadaan sapi bibit 34 } \\
\text { ekor @ Rp. 3.750.000 }\end{array}$ \\
2. $\begin{array}{l}\text { Becik Asih/ } \\
\text { Kebumen }\end{array}$ & 20 & 150.000 .000 & $\begin{array}{l}\text { Pengadaan sapi bibit } \\
40 \text { ekor @ Rp. 3.750.000 }\end{array}$ \\
\hline
\end{tabular}

Pengelolaan pengadaan ternak bibit dilakukan secara transparan, yakni peternak dan pengurus kelompok memilih sendiri sapi yang didatangkan pedagang, dengan pendampingan oleh tim teknis dari kabupaten dan provinsi, agar sapi yang dibeli sesuai dengan persyaratan teknis dan administrasi yang telah ditentukan. Pada pelaksanaannya, setiap paket bantuan (2 ekor per peternak) dibelikan ternak dalam kondisi bunting dan ternak siap kawin. Ternak bibit yang dibeli umumnya adalah Peranakan Ongole (PO).

\section{Manajemen Pemeliharaan dan Pakan}

Penerapan kandang kelompok merupakan syarat yang harus diterapkan penerima BPLM. Terkonsentrasinya ternak gaduhan dalam kandang kelompok akan mempermudah pengawasan ternak dan pelaksanaan IB dapat terpantau dengan lebih baik. Namun demikian di Kabupaten kebumen masih menerapkan sistem kandang individu. Alasannya, peternak masih belum mengalami masalah lahan untuk kandang dan domisili anggota tersebar. Pada tahun pertama dari pengembangan BPLM, tingkat hunian kandang kelompok di Kabupaten Banjarnegara adalah 100\%, Berbagai alasan yang disampaikan petani berkaitan dengan dimanfaatkannya kandang kelompok adalah lokasi kandang kelompok tidak jauh dari tempat tinggal (maksimum $1 \mathrm{~km}$ ), lingkungan pemukiman menjadi lebih bersih dan tidak banyak nyamuk, peluang petani berkomunikasi tentang budidaya sapi potong menjadi lebih besar.
Peternak di Kabupaten Banjarnegara dan Kebumen pada musim kering sepenuhnya mengandalkan jerami padi sebagai pakan. Peternak menyimpan jerami untuk keperluan pakan 3-4 bulan. Sesuai dengan pola tanam yang ada, di lokasi yang mengusahakan jagung, jerami diberikan pada bulan September. Pengambilan jerami jagung dilakukan secara bertahap yaitu 15 sampai 20 hari sebelum jagung dipanen. Pada tahun pertama pengembangan BPLM, peternak memperoleh bantuan konsentrat untuk kebutuhan sekitar 1 tahun, selanjutnya peternak mengusahakannya sendiri. Konsentrat yang umum diberikan peternak adalah dedak, karena selalu tersedia sepanjang tahun. Pemberian dedak bervariasi dengan kisaran 0,5-3 kg/ekor/hari. Selain dedak, peternak di Kabupaten Banjarnegara menambahkan jagung pada saat musim panen. Meskipun peternak telah memberikan pakan penguat, namun masih belum memperhatikan kondisi ternak. Agar dicapai kinerja reproduksi yang memuaskan, perlu strategi dalam pemberian pakan penguat, utamanya bulan pertama awal kebuntingan dan 2 bulan menjelang kelahiran.

\section{Manajemen Pupuk Kandang}

Manfaat sampingan yang diperoleh dari usaha sapi potong adalah dihasilkannya pupuk kandang. Menurut keterangan peternak, setiap ekor sapi setiap tahunnya menghasilkan sekitar 3,6 ton pupuk kandang. Pupuk kandang yang bercampur dengan dengan sisa pakan selama ini telah 
dimanfaatkan oleh peternak, terutama untuk tanaman palawija. Dalam pemanfaatannya sebagai pupuk, kotoran ternak tidak diproses terlebih dahulu, hanya ditampung begitu saja dan pada saat tertentu dilakukan pembalikan. Apabila kotoran sapi ditangani dengan baik melalui proses pengomposan, kotoran ternak dapat merupakan sumber pendapatan yang rutin bagi petani. Dalam model sistem integrasi padi-ternak (SIPT) yang dikembangkan Departemen Pertanian, tujuan utama pemeliharaan sapi adalah untuk menghasilkan kompos, sapi bakalan yang dihasilkan setiap tahun merupakan bonus.

\section{Manajemen Reproduksi}

Sapi yang telah dan sedang bunting di Kabupaten Kebumen dan Banjarnegara, masing-masing adalah $94,87 \%$ dan $82,35 \%$. Persentase tertinggi yang telah melahirkan di Kabupaten Banjarnegara (47,06\%) dan Kebumen (43,59\%). Tabel 3 menunjukkan perkembangan populasi ternak BPLM tahun awal (2003-2004). Dengan adanya kelahiran pedet maka telah menambah populasi ternak di masing-masing KTT, seperti terlihat pada Tabel 3.

Tabel 3. Perkembangan Populasi Ternak BPLM Tahun 2003-2004

\begin{tabular}{|c|c|c|c|c|c|c|}
\hline \multirow[t]{2}{*}{ No. } & \multirow[t]{2}{*}{ KTT/Kabupaten } & \multicolumn{2}{|c|}{$\begin{array}{c}\text { Populasi } \\
2003\end{array}$} & \multicolumn{3}{|c|}{$\begin{array}{l}\text { Populasi dan induk bunting } \\
2004\end{array}$} \\
\hline & & Induk & Anak & Induk & Anak & Bunting \\
\hline 1. & $\begin{array}{ll}\text { Bumi } & \text { Mulyo/ } \\
\text { Banjarnegara } & \end{array}$ & 34 & - & 34 & 16 & 12 \\
\hline 2. & Becik Asih/ Kebumen & 40 & - & 39 & 17 & 20 \\
\hline
\end{tabular}

\section{Analisis Finansial}

Lancar tidaknya operasionalisasi pola gaduhan dan perguliran di masing-masing kabupaten sangat tergantung sampai seberapa jauh ternak bibit menghasilkan anak. Analisis untuk menentukan apakah pola gaduhan dapat saling menguntungkan dan perguliran dapat berjalan sesuai dengan yang diharapkan serta modal kelompok ternak dapat berkembang, dilakukan dengan mengkaitkan antara kinerja reproduksi pada tahun pertama pengembangan BPLM dengan pola gaduhan.

Dalam analisis diasumsikan : 1) sapi gaduhan di IB dengan semen Simental atau Limousin atau Brangus; 2) harga pedet keturunan Simental atau Limousin / Brangus umur 6 bulan Rp. 3.000 .000 per ekor; 3) harga input dan output produksi serta angka kelahiran konstan selama masa gaduhan; 4) tenaga kerja untuk perawatan dan pencarian hijauan merupakan tenaga kerja keluarga yang nilainya tidak diperhitungkan sebagai input produksi.
Hasil analisa finansial usaha perbibitan sapi potong di Kabupaten Banjarnegara dan kebumen tercantum pada Tabel 4.

Di Kabupaten Banjarnegara rata-rata angka kelahiran belum memuaskan, yakni 47,06\%. Bila peternak tidak dibebani setoran porsi hasil penjualan pedet maupun bunga pinjaman, maka selama masa gaduhan, peternak memperoleh keuntungan Rp. 3.308.753,- serta masih memiliki 2 ekor induk (ternak pokok). Namun, keuntungan tersebut akan berkurang, karena penggaduh dibebani kewajiban menyetorkan kepada kelompok $50 \%$ dari hasil penjualan pedet jantan. Tahun pertama dari pengembangan BPLM di Kabupaten Kebumen ditandai dengan masih rendahnya rata-rata angka kelahiran, yakni 43,59\%. Diprediksikan hasil penjualan pedet tidak mampu untuk menutup biaya produksi maupun pengembalian pinjaman, sehingga pada akhir masa gaduhan terdapat defisit $\mathrm{Rp}$. 2.051.583,-. Apabila kondisi ini tidak mengalami perbaikan maka di akhir masa gaduhan peternak harus menjual induk 
untuk mengembalikan pinjaman pokok. reproduksi ternak bibit dan atau jangka Untuk itu perlu upaya peningkatan kinerja waktu pelunasan perlu ditinjau ulang.

Tabel 4. Analisa Finansial Usaha Perbibitan Sapi Potong (2 ekor per penggaduh)

\begin{tabular}{clcc}
\hline \hline No. & \multicolumn{1}{c}{ Uraian } & Banjarnegara & Kebumen \\
\hline 1. & Jangka waktu gaduhan (tahun) & 4 & 3 \\
2. Porsi setoran anak (\%) & 0 & 30 \\
3. Rata2 angka kelahiran (ekor) & 0,94 & 0,87 \\
4. Rata2 total kelahiran selama masa gaduhan & 3,7648 & 2,6154 \\
(ekor) & & \\
5. Nilai penjualan anak (Rp.) & 11.294 .400 & 7.846 .200 \\
6. Nilai kotoran ternak & 1.440 .000 & 1.080 .000 \\
7. & Total output (5+6) (Rp.) & 12.734 .400 & 8.926 .200 \\
8. Input (Rp.): & & \\
a. Konsentrat induk & 1.095 .000 & 730.000 \\
b. Konsentrat anak & 5.647 & 3.923 \\
c. Penyusutan kandang & 200.000 & 150.000 \\
d. IB & 360.000 & 240.000 \\
e. Bunga pinjaman & 0,000 & 0,000 \\
f. Nilai porsi setoran anak & 0 & 2.353 .860 \\
g. Pinjaman pokok & Total input & 7.765 .000 & 7.500 .000 \\
10. Output-Input (7-9) & 9.425 .647 & 10.977 .783 \\
\hline
\end{tabular}

Keterangan : Rata2 total kelahiran selama masa gaduhan $=2$ ekor induk X rata-rata angka kelahiran X jangka waktu gaduhan

\section{Kinerja Kelompok}

Sebagian besar KTT penerima BPLM telah terbentuk selama 2-3 tahun. Umumnya KTT berasal dari kelompok hamparan yang kemudian membentuk cabang usaha bidang peternakan. Komponen yang ada pada struktur organisasi kelompok adalah ketua, wakil ketua, sekretaris I dan II, bendahara I dan II, serta seksi-seksi (sapronak, produksi, pemasaran, kesehatan hewan, dan pengembangan SDM). Aturan yang ditetapkan kelompok dan ditaati anggota pada lokasi yang menerapkan kandang kelompok adalah digunakannya kandang kelompok secara berkelanjutan, iuran listrik dan air, giliran jaga malam pada kandang kelompok. Seluruh pengurus KTT mampu mengadakan pertemuan rutin bulanan maupun selapanan (35 hari) dengan tingkat kehadiran anggota $>75 \%$ pada setiap kali pertemuan. Pertemuan kelompok merupakan wahana yang efektif untuk saling menyampaikan informasi yang berkaitan dengan hal teknis budidaya sapi potong. Apabila terdapat permasalahan teknis yang tidak dapat dipecahkan oleh anggota, maka penyuluh setempat diundang pada pertemuan kelompok untuk memberikan bimbingan. Pada subsistem penyediaan sarana produksi, masih sebatas konsolidasi dalam penyediaan pakan penguat dan pemasaran. Seksi pemasaran bertugas mencari peluang pasar, yakni memilih pedagang yang diketahui kredibilitasnya dapat 
dipertanggungjawabkan (tidak menipu). Kemampuan pengurus KTT dalam hal pembukuan masih perlu ditingkatkan. Untuk itu, perlu peningkatan kemampuan pengurus kelompok dalam mengelola usaha melalui pelatihan dan pendampingan teknologi.

\section{Lembaga Keuangan Mikro}

Salah satu sasaran dari pengembangan BPLM adalah tumbuhnya Lembaga Keuangan Mikro (LKM) di tingkat kelompok ternak. Hal ini sejalan dengan kebijakan Departemen Pertanian, bahwa dalam rangka mengatasi masalah permodalan di kalangan petani perlu didorong tumbuhnya LKM Agribisnis yang berasal dari embrio program pengembangan kelompok dana bergulir (Sumodiningrat, 2003). Lembaga keuangan mikro pada pengembangan BPLM mempunyai peluang untuk berkembang mengingat kelompok diberi wewenang untuk mengelola kewajiban finansial. Selain itu, pada tahun kedua ketua kelompok diberikan kebebasan untuk membentuk / mempersiapkan calon penerima perguliran di bawah bimbingan Tim Pembina Teknis dari dinas yang membidangi peternakan di masing-masing kabupaten. Dengan dikelolanya perguliran oleh kelompok maka peluang berkembangnya agribisnis di suatu kawasan akan semakin besar. Peningkatan jumlah peternak penerima bantuan akan meningkatkan skala usaha di tingkat kelompok, sehingga akan mendorong agribisnis sapi potong secara efisien.

Sumber keuangan bagi

berkembangnya LKM berasal dari dana penjualan pedet yang disetor dan bunga pinjaman dialokasikan untuk penambahan / pengembangan modal kelompok. Pengalokasian tersebut tidak terjadi di Kabupaten Banjarnegara, karena tidak adanya sumber pemasukan. Di Kabupaten Banjarnegara peternak tidak dibebani beban bunga pinjaman, selain itu peternak berhak sepenuhnya terhadap pedet yang dihasilkan sapi gaduhan. Namun perkembangannya, anggota dan pengurus kelompok menyepakati bahwa peternak diwajibkan menyetor $50 \%$ hasil penjualan pedet kepada kelompok jika pedet yang dilahirkan jantan. Secara keseluruhan, LKM belum menunjukkan perkembangan yang berarti, hal ini disebabkan karena sebagian besar penggaduh belum menyetorkan kewajibannya pada kelompok, sehingga belum ada pemupukan modal ada kelompok.

\section{KESIMPULAN}

Pendekatan partisipatif pada pola BPLM dilakukan mulai perencanaan, mengelola BPLM sampai pada manajemen perguliran. Tim Pembina Teknis dari dinas seyogyanya secara terus menerus melakukan pemantauan. Agar dicapai keuntungan yang maksimal, maka ternak sapi diusahakan dapat mencapai jarak beranak (calving interval) 12 bulan. Diperlukan pelatihan ketrampilan peternak untuk mengamati siklus birahi dan sistem pelaporan permintaan IB oleh peternak ke inseminator.

Di Kabupaten Banjarnegara dan Kebumen, setelah selesai masa BPLM ternak pokok menjadi hak penggaduh. Terhadap hak atas pedet yang dihasilkan selama masa BPLM di Kabupaten Banjarnegara berhak 100\%, di Kabupaten Kebumen berhak 70\%. Terhadap kewajiban mengembalikan pinjaman pokok, penggaduh di Kabupaten Banjarnegara dan Kebumen mengembalikan sejumlah uang dengan jumlah sesuai pada saat akad kredit. Dalam perkembangannya, anggota dan pengurus kelompok di Kabupaten Banjarnegara membuat kesepakatan yang berbeda dengan yang diatur dalam surat perjanjian. Di Banjarnegara dibuat kesepakatan apabila pedet yang dihasilkan betina maka setelah berumur 15 sampai 18 bulan digulirkan kepada anggota yang belum memperoleh bantuan, namun jika yang dihasilkan pedet jantan maka hasil penjualan dibagi $50 \%$ : $50 \%$, masingmasing untuk hak penggaduh dan setoran ke kelompok.

Di Kabupaten Kebumen diprediksi mengalami defisit masing-masing Rp. 
2.051.583. Agar di akhir masa gaduhan peternak tidak harus menjual ternak pokok untuk melunasi kewajibannya, perlu upaya yang keras untuk meningkatkan kinerja reproduksi ternak bibit disertai dengan peninjauan ulang jangka waktu pelunasan.

\section{DAFTAR PUSTAKA}

Dinas Peternakan Propinsi Jawa Tengah. 2004. Statistik Peternakan Propinsi Jawa Tengah. Ungaran.

Diwiyanto K. dan Handirawan 2004. Pengembangan Sistem Agribisnis Peternakan Pusat Penelitian dan Pengembangan Peternakan. Puslitbangknak, Bogor.

Hardjosubroto, W. 2003. Pola Pemuliabiakan Untuk Peningkatan Produktivitas Ternak Lokal di
Indonesia. Prosiding Seminal Nasional Peternakan dan Veteriner, Puslitbangknak, Bogor.

Kariyasa dan Kasryno. 2004. Dinamika Pemasaran dan Prospek Pengembangan Ternak Sapi di Indonesia. Badan Litbang Pertanian, Jakarta.

Slamet.1994. Pembangunan Masyarakat berwawasan Partisipasi. Sebelas Maret University Press, Surakarta.

Soekartawai. 1993. Prinsip Dasar Ekonomi Pertanian. Teori dan Aplikasi, Edisi Revisi. PT. Raja Grafika Persada, Jakarta.

Sumodiningrat, G. 2003. Pengelolaan dan Pengembangan Badan Kredit Pedesaan. Kredit Pedesaan di Indonesia. BPFE. Universitas Gadjah Mada, Yogyakarta. 